\title{
Méditerranée
}

Revue géographique des pays méditerranéens / Journal of Mediterranean geography

$130 \mid 2018$ :

Portugal, a country in transformation

A perspective on sustainable environment

\section{Changes in mainland Portuguese forest areas since the last decade of the XXth century}

Changements des zones forestières portugaises depuis la dernière décennie du XXe siècle

\author{
António Bento-Gonçalves, ANTónio Vieira, Luís da Vinha AND \\ SAFA'HAMADA
}

\begin{abstract}
s
English Français

According to data from the Forests and Nature Conservation Institute (ICNF), the potential land suitability in Portugal for forest use is estimated to be about 59.4\% (5.3 million hectares). However, according to the 6th National Forest Inventory, published in 2010, the effective area occupied by forests is only $35.4 \%$. In the present work, we analyze the evolution of land use in mainland Portugal since the last quarter of the twentieth century, with a particular focus on forest areas.

Selon les données de l'Institut de conservation de la nature et des forets, au Portugal la superficie que l'on pourrait potentiellement réserver à l'usage forestier serait d'environ 5,3 millions d'hectares (59,4\% du territoire). Toutefois, si l'on en croit le 6e inventaire forestier national, en date de 2010, la superficie réelle occupée par la forêt est de 35,4\%. Dans cette étude, nous analysons l'évolution de l'usage des terres et l'occupation du sol dans la partie continentale du Portugal depuis la dernière décennie du vingtième siècle, avec une attention particulière pour les zones forestières.
\end{abstract}

\section{Index terms}

Mots-clés : Utilisation du sol, zones forestières

Keywords : Land use, forest areas

Geographical index : Portugal, European SW

\section{Full text}




\section{Introduction}

As humans settle a particular portion of territory, they create a host of different spaces which LEMA \& REBELO (1997) group into five different categories: rural areas, forest areas, urban areas, industrial areas, and coastal areas. However, many times the natural suitability of the environment - i.e. (...) the potential proclivity of the territory in accordance with the natural resources available (HENRIQUES, 1991) - is not respected and the actual land use does not conform to the potential land use. In other words, certain areas are disposed to certain uses that are not always effectively employed by societies.

2 In addition, while the concepts of land use and land cover are complementary, they present different objectives. Land use refers to the "identification of the economic or social purpose for which the land is used" (IFN, 2009), whereas land cover involves "the identification of the physical or biological land cover" (IFN, 2009).

When analyzing the real and potential land use in Portugal we verify important discrepancies that raise several questions. Identifying the potential of a particular geographic space and associating it to reality demands a significant effort to conciliate contradictory forces and dynamics.

$4 \quad$ The estimated value of the potential land use capacity should be critically analyzed. There are several considerations that should be taken into account, namely geomorphology, edaphoclimatic characteristics, and socioeconomic and structural determinants. Nevertheless, this conflict of values reveals that in Portugal the actual land use differs from potential use. This creates areas in which their potential are not being appropriately exploited, as is the case with forest areas.

\section{Concepts}

Although the two concepts are many times used interchangeably, land use and land cover are two complementary concepts that have different objectives. Land use implies a mix between a particular type of use and type of settlement that creates a great variety of uses for the land (DEÀK, 1985). The land cover concept ascertains the existing species or types of habitats in a more detailed fashion in accordance with the analytical objectives at hand.

6 The nature of this conceptual distinction generates a new type of problem: the dichotomy between potential land use and real land use. Potential use refers to the suitability of the environment for certain uses, whereas real use refers to the actual use that a particular area is subject to. These are concepts which are important for the planning and management of forest areas. In particular, their distinction is essential in enabling the areas' productivity to be increased. Taking advantage of a potential land use increases productivity and decreases the potential impact because the soil and its uses are then in a seamless symbiosis. On the other hand, when real use differs from potential use we find an inappropriate situation in which, on many occasions, the results are far below the latent prospects made available by the land.

7 This problematic situation can be illustrated using expressions such as land qualification and classification. "Land classification and qualification are urban planning techniques" (MAODR, 2007) used in spatial plans and which are based on the identification of the dominant land use (actual and/or future) in accordance with analyses that take into consideration biophysical, social, economic, and political characteristics. These procedures focus on the dominant land use rather than the potential land use.

\section{1 - Land Cover and Land Use in Mainland Portugal}


8 From a biogeographic perspective, mainland Portugal is located in the Holarctic Realm. More precisely, it is on the borders of two distinct biogeographic regions: the Atlantic sub-region of the Euro-Siberian region and the Mediterranean region (fig. 1).

Fig. 1 - Floristic regions in Europe according to Wolfgang Frey and Rainer Lösch

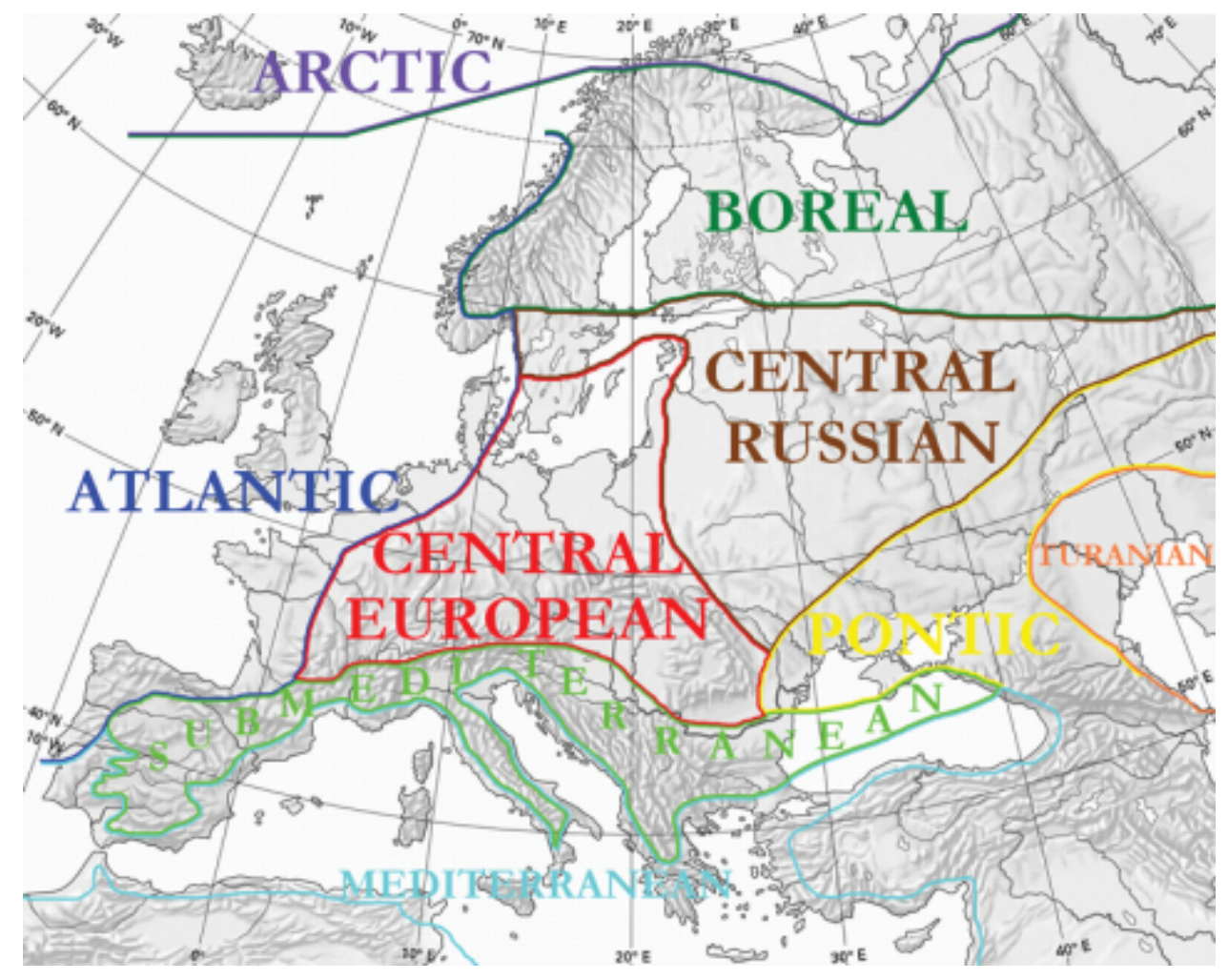

Source: https://commons. wikimedia.org/w/index.php?curid=3790054.

The regions most influenced by the Atlantic (Atlantic and Pre-Atlantic - Climate characterized by mild temperatures, low thermal amplitudes and high atmospheric humidity that translates into rainy winters with moderate temperatures and short summers, with moderate temperatures thanks to the humidity coming from the ocean) are predominantly located north of the Tejo River, whilst those regions most influenced by the Mediterranean (interior Pre-Mediterranean, coastal Pre-Mediterranean, and Mediterranean - Climate strongly influenced by continental air masses African and Euro-Asian that results in mild winters and summers with long summer periods, with high average temperatures and significant atmospheric dryness) are essentially located south of the Tejo River, in the northern and central highlands, and in the slopes of the Douro river valley, the Terra Quente Transmontana, and lowland southern valleys (RIBEIRO et al., 1999).

10 These (sub)regions are, therefore, biogeographically, distinct. In the Atlantic subregion the most representative climatic formations are "forests of soft, flat, large, deciduous leaves," whereas in the Mediterranean region the "forests and shrub lands with small, leathery and persistent flat leaves" predominate (RIBEIRO et al., 1999).

\section{1 - Spatial Planning and Environmental Policies}

Portugal is a highly fragmented country from both a socioeconomic and environmental perspective. There are multiple contrasts, such as between the coastal and interior regions and the North and South.

Concerning the issues of the unequal development of the national territory, we can verify that state intervention-translated by the construction and consolidation of a regional policy-goes back to 1968 and to the III Plano de Fomento (Third Development Plan) and remains a dominant concern insofar as, despite this intervention, there has been a reinforcement of the asymmetries in regional development.

Therefore, it was during the Third Development Plan, active in 1968-1973, that concerns arose regarding regional imbalances, namely emphasizing their causes and 
mitigating measures, and that planning came to the forefront in Portugal (REIGADO, 1983).

With the institutional breakdown resulting from the revolution of 25 April 1974, the IV Plano de Fomento (Fourth Development Plan), which had begun in December 1973, was interrupted, and only in February 1975 did the Economic and Social Policy Program appear. However, this program cannot be considered a mid-range plan since its main goal was to identify the general objectives to be pursued and which were ultimately the result of the most pressing national concerns - e.g., social housing and food supply.

15 A key factor contributing to Portuguese development, particularly in terms of spatial planning and environmental protection, was the adhesion to the European Economic Community (EEC) in January 1986. From that date forward, the country was subject to European laws.

One of the legislative pillars that followed the adhesion to the EEC was the Basic Law of the Environment (Lei de Bases do Ambiente), Law no. 11/87 of April 7. This law created the basis for the national environment policy and established a set of concepts, principles, objectives, and instruments that guide policy and give it the material content and the means of implementation.

17 In terms of spatial planning, the integration of disparate legal instruments was not achieved until the end of the 1990s. There was some early progress made by several legislative initiatives which resulted in the creation of a set of spatial planning tools: in 1982 the Municipal Master Plans (PDM) were instituted by the Law-Decree no. 208/82, of 26 May; in the following year the Regional Spatial Plans (PROT) were created under the Law-Decree no. 338/83, of 20 July; in 1990, Law-Decree no. 69/90, of 2 March, provided the first attempt to integrate several different "instruments" of spatial planning; in 1993, the Special Spatial Plans (PEOT) were created, which, according to the same document, were to be articulated with other territorial planning instruments (Law-Decree no. 151/95, of 24 June). Finally, in 1998, with Law-Decree no. 48/98, of 11 August, the nation had a Basic Law for Spatial Planning and Urban Development (Lei de Bases da Política de Ordenamento do Território e de Urbanismo) which provides a global definition of the policy objectives and principles, namely defining the actions promoted by Public Administration. In particular, the law determines that the administration's aim is to ensure an adequate organization and use of the national territory, in order to achieve the integrated, harmonious, and sustainable economic, social and cultural development of the country (with particular emphasis on the different regions and urban agglomerations). The law also established a coherent and articulated set of Territorial Management Instruments (IGTs) at the national, regional, and local level on which it is based and which constitutes the territorial management system (SGT).

18 More recently, in May 2006, the National Spatial Planning Program (PNPOT) was presented. The document provides the strategic guidelines for all the territorial management instruments, establishing a national strategic framework that guides the other IGT.

19 The History of Portugal demonstrates that one of the country's greatest problems over the last two centuries has been economic and demographic instability. These factors have created significant disorders in the organization of the nation's different regions and landscapes. Despite the political stability of the last two decades, the country's progress in economic development and urbanization did not correspond to the consolidation of a model of sustainable development, nor did it generate a consensus on a common project for the national territory (PNPOT, 2006).

\section{2 - Forest Spaces}

In 1868, the "Report on the General Arborization of the Country" was published by Carlos Ribeiro and Nery Delgado at the request of the Geographic Institute. The report was a direct response of the Minister of Public Works, Commerce and Industry to the Requirements of Article 1 of the Decree of 21 September 1867 and can be considered the 
starting point for the contemporary history of the forest in mainland Portugal. The map included in this report, despite its exaggerated scale and simplified representation, revealed extensive areas with a strong afforestation potential (fig. 2). In fact, the main objective was to identify the areas with adequate conditions to promote the forest development of the country.

\title{
Fig. 2 - Excerpt from the map accompanying the "Report on the General Arborization of the Country"
}

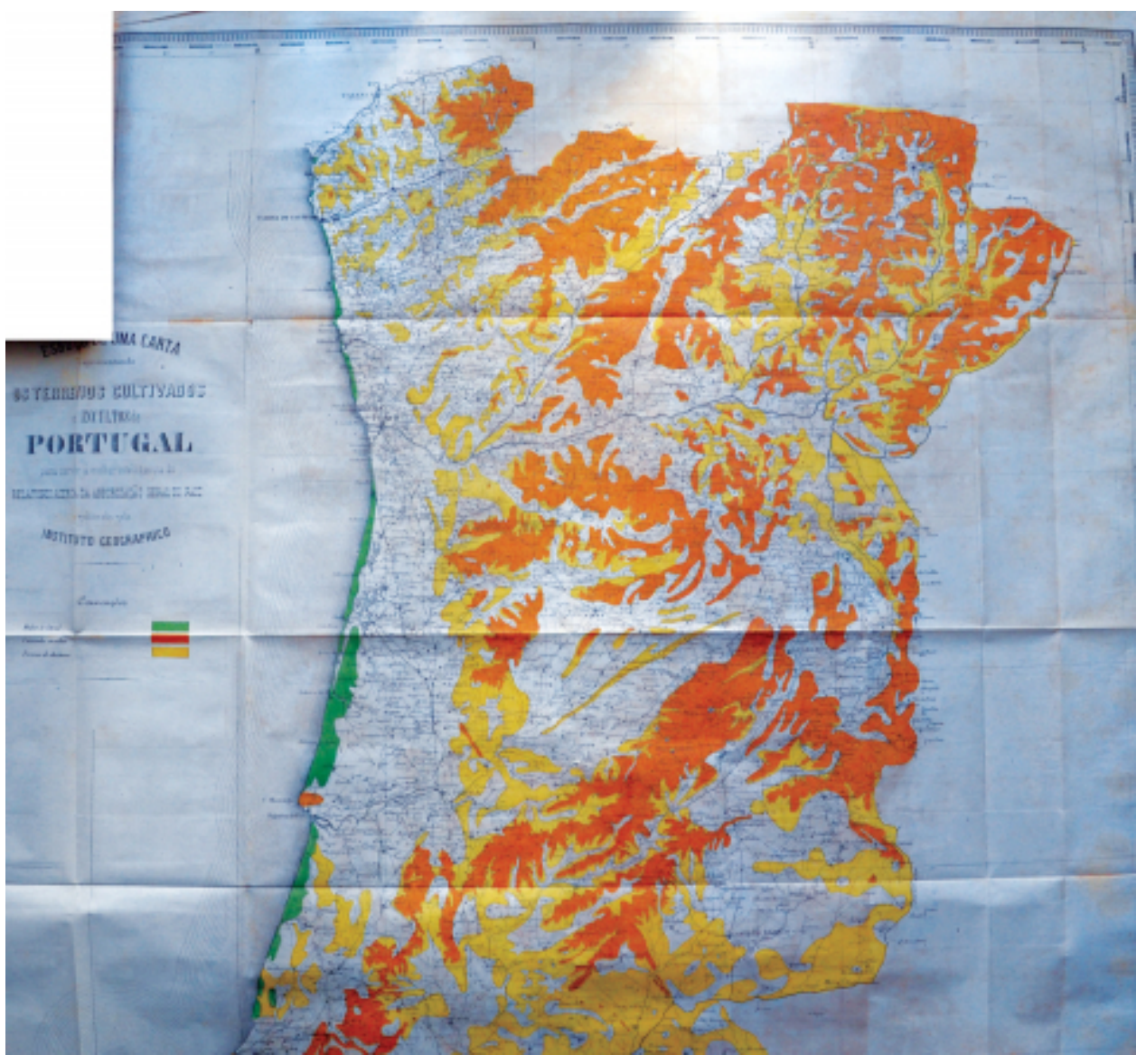

As RADICH et al. (2005) have clarified:

Between 1875 and 1938, the forest areas in Portugal may have grown by about one million and eight hundred thousand hectares," although "the sowing areas implemented by the public services between 1886-87 and 1936 amounts to just over 50,000 hectares, of which 25,000 are in the dunes, 18,000 in the mountains, the rest in stable terrains.

This forestry policy resulted in the establishment of

\begin{abstract}
an almost monoculture of maritime pine, a pioneer species of ecological succession capable of surviving even in extremely degraded soils. These characteristics, coupled with rapid growth and the prospect of obtaining timber of commercial value in an acceptable time frame, have in fact led to the use of maritime pine. However, its extraordinary capacity to colonize land left free by the abandonment of agriculture has been responsible for a very substantial part of the area it currently occupies" (APIF, 2005).
\end{abstract}

Since the end of World War II, a shift in the orientation of state policy towards the forestry sector has begun, favoring the support of private forest ownership. Thus, under the Second Development Plan (1959-1964), reinforced in 1965 by the Interim Development Plan (1965-1967), a shift began in which the State promoted afforestation on the most fertile and increasingly neglected private lands. Hence, the investment would have guaranteed better reproductive conditions and the afforestation would involve less social conflicts.

The period between 1965 and 1975 coincides approximately with the period of the Colonial War, a period marked by intense emigration. In 1965 the Forest Development 
Fund was created, which, from 1969 to 1974, promoted afforestation, especially in the districts of Beja, Évora, Faro, and Portalegre (south of Portugal). During this period, the depopulation of the interior of the Portuguese mainland coincided with the reduction of human and financial resources devoted to the agroforestry system. This was combined with the fact that the forest stands resulting from the afforestation carried out until the 1920 seached or were close to reaching adulthood.

Contrary to what had hitherto occurred, the populations, substantially smaller in number, had to deal with a new reality:

1. Existence of a forest where once the landscape was bare and where they once grazed cattle or gathered the shrubs;

2. Stands of pine trees that, in some places, replaced the hardwood forests;

3. Increase of stands with a high fuel load, due to socioeconomic changes that, in the meantime, had occurred.

People were not accustomed to dealing with this new situation and were not prepared for the changes. Those individuals who remained continued (and continue) to work in their routine agroforestry practices as they had always done. In other words, the entire physical and human structure implemented throughout half a century had collapsed due to the lack of financial and human resources. The abandonment of the fields generated a landscape of neglect in which shrubs and pine forest settled and created conditions prone to the occurrence of forest fires. In a territory lacking management or with poor management of its new forest resources and a poor surveillance structure, by both the private sector and the State, large fires have started to appear.

The April 1974 revolutionary process brought profound changes to the Portuguese society which was reflected in the organization and political orientation of public institutions, including the Forest Services. From 1975 to 1985, there was a loss of important forest stands created by the Plan of Forest Settlement due to the wave of fires that began in the mid-1970's. The attempts to establish a set of forest management models that could safeguard this resource to ensure the evolution towards an ecologically and socially more valuable forest system was disregarded - despite the fact that the path was already outlined in 1938 and the strands having been managed in accordance to norms that differed little from those of mid-century (PINHO, 2000).

From 1986 to 1996, the problem of the loss of competitiveness and attractiveness of investment in the Portuguese forest, with its consequent increasing exposure to abandonment and the risk of fire, was exacerbated. In fact, during this period the forested areas reach their peak, although they are recognized to be largely subexploited, of low economic value, exposed to extreme risk, and face a growing number of phytosanitary problems (IFN, 1995).

\section{3 - The Evolution of Land Use in Mainland Portugal since 1990}

The evolution of land use and occupation in Portugal reflects, therefore, the inefficacy of land management strategies and the faulty implementation of the management tools necessary to ensure that the potential of the soil is adapted to its "appropriate" use.

The introduction of spatial planning and environmental policies has promoted the identification and definition of land management guidelines. However, these guidelines are always constrained by the demographic, economic, and environmental dynamics of each particular historical period.

29 The advent of geographic information technologies has allowed for the measurement of geographic information over wider areas, helping synthesize the information regarding land occupation, as well as expanding the capacity to analyze its evolution. Thus, based on the information provided by the CORINE Land Cover cartography ${ }^{1}$ for the years 1990, 2000, 2006, and 2012, it is possible to analyze soil occupation in 
mainland Portugal and verify that it has undergone slight changes, taking into consideration the large groups of land use (table I).

Table I

\begin{tabular}{lcccc} 
& $\mathbf{1 9 9 0}^{\mathbf{a}}$ & $\mathbf{2 0 0 0}^{\mathrm{b}}$ & $\mathbf{2 0 0 6}^{\mathrm{C}}$ & $\mathbf{2 0 1 2}^{\mathbf{d}}$ \\
\hline Built-up areas & 1.9 & 3.2 & 3.7 & 3.8 \\
\hline Agricultural areas & 48.8 & 47.7 & 46.8 & 46.7 \\
\hline Wildland areas & 48.0 & 47.8 & 47.9 & 47.9 \\
\hline Others & 1.3 & 1.4 & 1.6 & 1.6 \\
\hline
\end{tabular}

Land use between 1990 and 2012, by large groups of land use (\%).

Source: a) CLC, 1990; b) CLC, 2000; c) CLC, 2006; d) CLC, 2012.

Accordingly, during the last decade of the twentieth century and the beginning of the twenty-first century, several socio-economic dynamics promoted a differentiated evolution of the different types of land use. One of the most relevant aspects was the continued growth of the built-up areas. These changes were clearly influenced by the economic development felt in the country after joining the European Economic Community in 1986.

31 In contrast, agricultural areas suffered a progressive decline in the area affected as a consequence of the socio-demographic changes that have affected Portugal over the past few decades (e.g., aging population, rural exodus, abandonment of agricultural activity due to its unattractiveness for the younger generations, etc.) (BENTO-GONÇALVES et al., 2010, LOURENÇO L. et al., 2012, FERREIRALEITE et al., 2016).

When analyzing wildland areas, considered here as the areas characterized by the presence of forests and semi-natural vegetation, we can verify that the evolution of the occupied areas during the period under consideration was non-linear. While there was a reduction in area until 2000, a slight recovery was noted with the increase in the area occupied in 2006 and 2012.

33 Bearing in mind Table II and the data regarding land use in 2012, and taking into consideration the enhanced disaggregation of the types of land use, the value of agricultural areas, forest areas, and shrub areas was equivalent to $93.4 \%$ of the total national territory. Thus, the preponderance of the spaces used for agriculture and forests or covered by semi-natural vegetation is evident (table II).

Table II

\begin{tabular}{rr|}
\hline Land use (2012) & $\%$ \\
\hline Built-up areas & 3.8 \\
\hline Agricultural areas & 46.7 \\
\hline Forest areas & 22.6 \\
\hline Semi natural vegetation areas & 24.1 \\
\hline Others & 1.2 \\
\hline Wetlands and water & 1.6 \\
\hline Total & 100.0 \\
\hline
\end{tabular}

Land use in mainland Portugal, 2012.

Source : CLC 2012.

However, when compared to 1990 (CORINE Land Cover 1990), built-up areas grew from $1.9 \%$ to $3.8 \%$, especially in the littoral fringe and in metropolitan areas (fig. 3 ).

Fig. 3 - Distribution of land covers in mainland Portugal, 1990 and 2012 


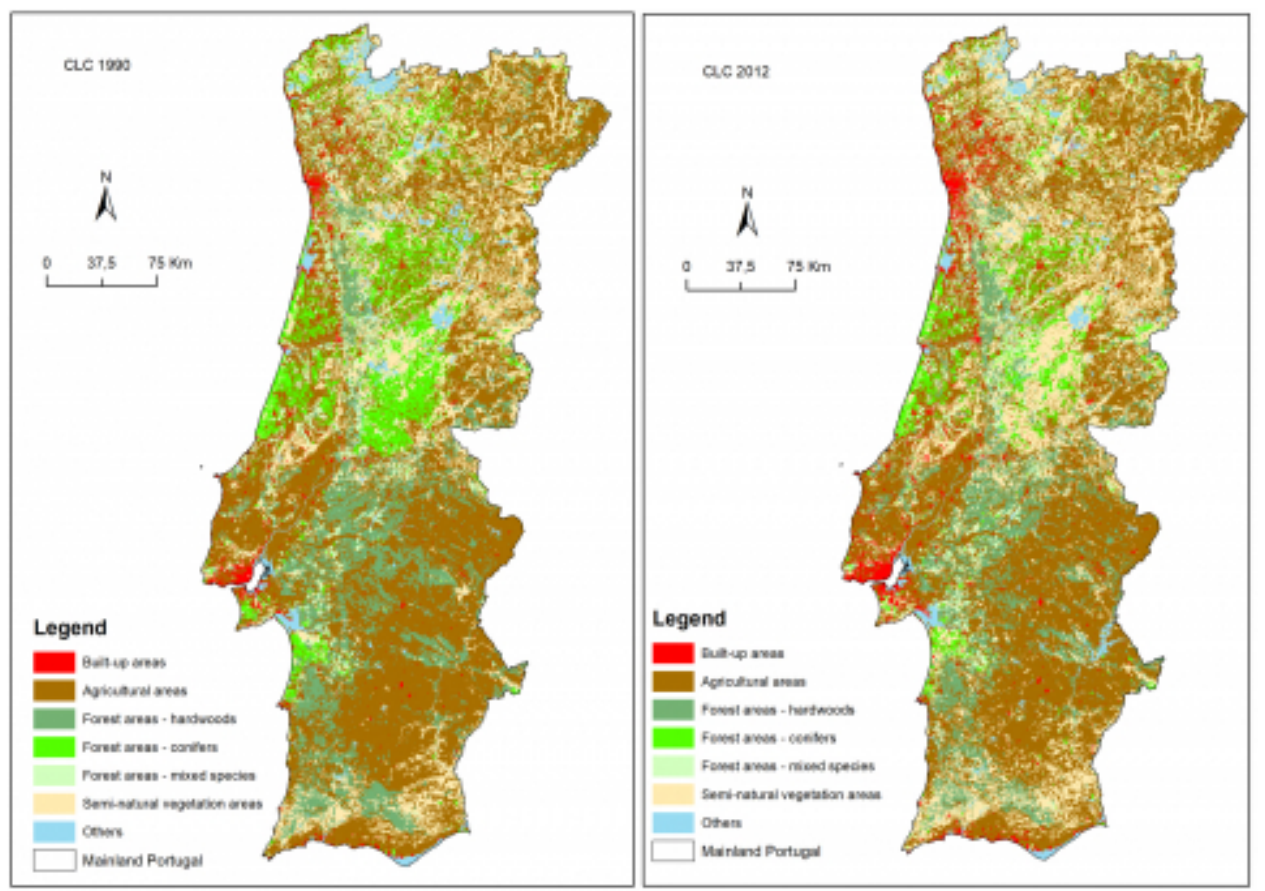

Source: CLC, 1990 and 2012; DGT.

As is well known, modern, more "developed" societies pursue a process of urbanization which, by concentrating too much of the population in a limited space, often leads to an improper use and organization of the territory. This tendency has contributed to Portugal's demographic bipolarization between the coastal and inland regions. Although these different spaces often overlap or even present relations of great functional promiscuity with the current models of development, the asymmetries that have long existed in the Portuguese territory (north versus south and, especially, coastal versus inland regions) are growing.

These deep divisions, which increase rather than contract, enhance the physical vulnerabilities of the territory and reduce the sustainability conditions that each of these different types-i.e., urban-rural/forest, coastal-inland, valley-mountainspresent. According to the data from CLC 2012, the most representative class corresponds to agricultural areas, with $46.7 \%$ of the total area. The built-up areas correspond to almost 4\% of the Portuguese mainland (approximately 334.996 hectares). Within this class, the discontinuous urban areas prevail, followed by industrial and mining, areas and the continuous urban spaces.

The area occupied by agriculture reaches 4,161,794 hectares, $31.05 \%$ of which correspond to the "pure" agricultural class, while $15.67 \%$ correspond to the blend of agricultural areas and natural spaces and forests. Agriculture in natural areas represents about 1.4 million hectares distributed in two types: $44.9 \%$ in agroforestry systems (predominantly located in the Alentejo region) and the remaining $55.1 \%$ in agriculture with natural spaces. The areas that registered the greatest decrease of agricultural space are concentrated in the metropolitan areas. These areas tend to favor artificialized territories.

38 Forest areas represent about $22.6 \%$ of the Portuguese mainland (2,012,886 hectares) distributed in hardwoods, conifers, and mixed species (Table III).

Table III

\begin{tabular}{|c|c|c|c|c|}
\hline \multirow[t]{2}{*}{ Land use } & \multicolumn{2}{|c|}{1990} & \multicolumn{2}{|c|}{2012} \\
\hline & $\%$ & ha & $\%$ & ha \\
\hline Hardwoods & 46.5 & $1,150,304$ & 51.1 & $1,027,883$ \\
\hline Conters & 31.4 & 776,239 & 23.9 & 480,657 \\
\hline Mixed species & 221 & 547,133 & 25.1 & 504,344 \\
\hline Sub-Total & & $2,473,677$ & & $2,012,886$ \\
\hline Semi natural vegetation & & $1,702,062$ & & $2,226,718$ \\
\hline Total & & $4,175,760$ & & $4,239,604$ \\
\hline
\end{tabular}

Distribution of forest areas by species group in mainland Portugal (1990 and 2012).

Source: CLC, 1990 and 2012. 
39 Between 1990 and 2012, this specific land use and occupation class (forests) decreased by 460,791 hectares, essentially due to the conversion of forest stands to other types of land cover areas. The semi-natural vegetation gained a great portion of it, and represents $25 \%$ of the total territory (2,226,718 hectares). Between 1990 and 2012, this land cover class increased considerably, by around 524,636 hectares-the largest increase in all classes analyzed. Geographically, it was in the Central and Algarve regions where the greatest increase was recorded (fig. 3). This was due, as we previously mentioned, to the conversion of forest and agricultural areas.

40 Taking into consideration figure 4, we can clearly identify and spatialize the main changes that have affected mainland Portugal during the analysis period.

Fig. 4 - Changes in land cover in mainland Portugal between 1990 and 2012

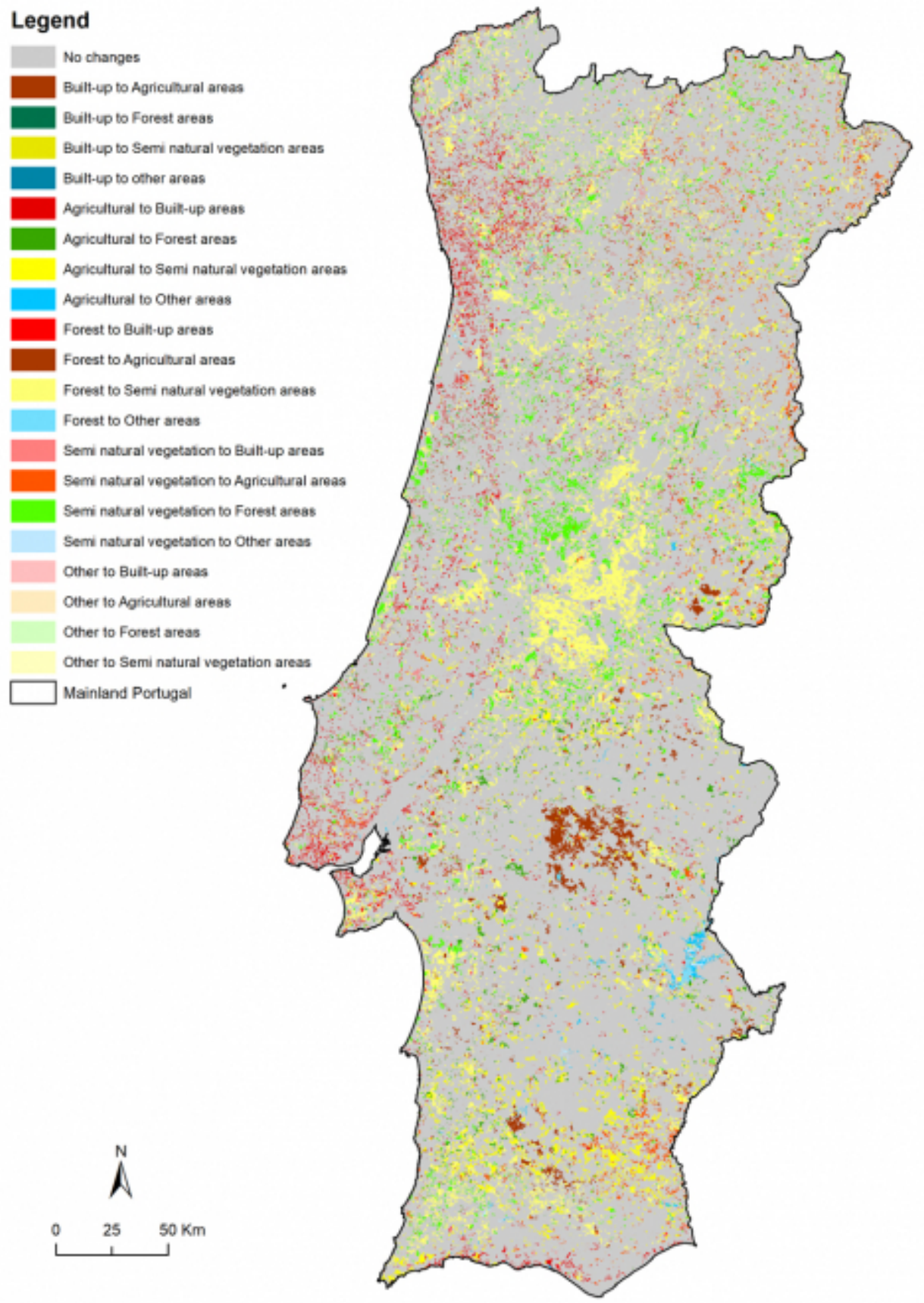

Source: CLC, 1990 and 2012; DGT

In fact, although the growth of built-up areas may be reflected in almost all the territory, it is more significant in the littoral fringe and in the metropolitan areas of Lisbon and Oporto. The attractiveness of the biggest urban areas allows for the continuing expansion of this land use.

On the other hand, agricultural areas contract. Nevertheless, in specific areas with higher agricultural potential, agriculture develops and occupies vast areas, benefiting 
from some major infrastructural initiatives such as the Alqueva Multiple Purpose Enterprise. This allowed for the growth of agricultural areas in the Alentejo region, in the central-south part of Portugal.

43 Forests and semi-natural vegetation areas grow all over the country, but more significantly in the central part of the territory, corresponding mainly to inland and mountain areas, with a limited potential for other uses and low population density. In fact, despite its important value for the Portuguese economy, and as stated previously, forests are subject to a very high and increasing risk: fire. Each year, thousands of hectares are consumed by fires, destroying and devaluating this valuable natural resource. The high risk of being burnt and the consequent growth of expenditure on restoration conducts to the abandonment of forested lands by landowners.

Even if they don't account completely for the reduction of forest areas, forest fires contributed extensively to this withdrawal. In figure 5 we observe a major fluctuation in the yearly burnt surface, the sum resulting in a strong impact on forests, increasing its fragmentation and greatly reducing its ground coverage.

We can identify relatively low values, below 33,00o hectares, in 1988, 1997, 2006, 2007, and 2008. But, on the other hand, the years 1991, 1995, 1998, 2000, and 2013 registered extremely high values, way above 150,000 hectares. We need to point to the years 2003 and 2005, which reached unprecedented highs $(425,839$ and 339,088 hectares, respectively).

Fig. 5 - Evolution of burned areas in mainland Portugal between 1981 and 2013 (ha)

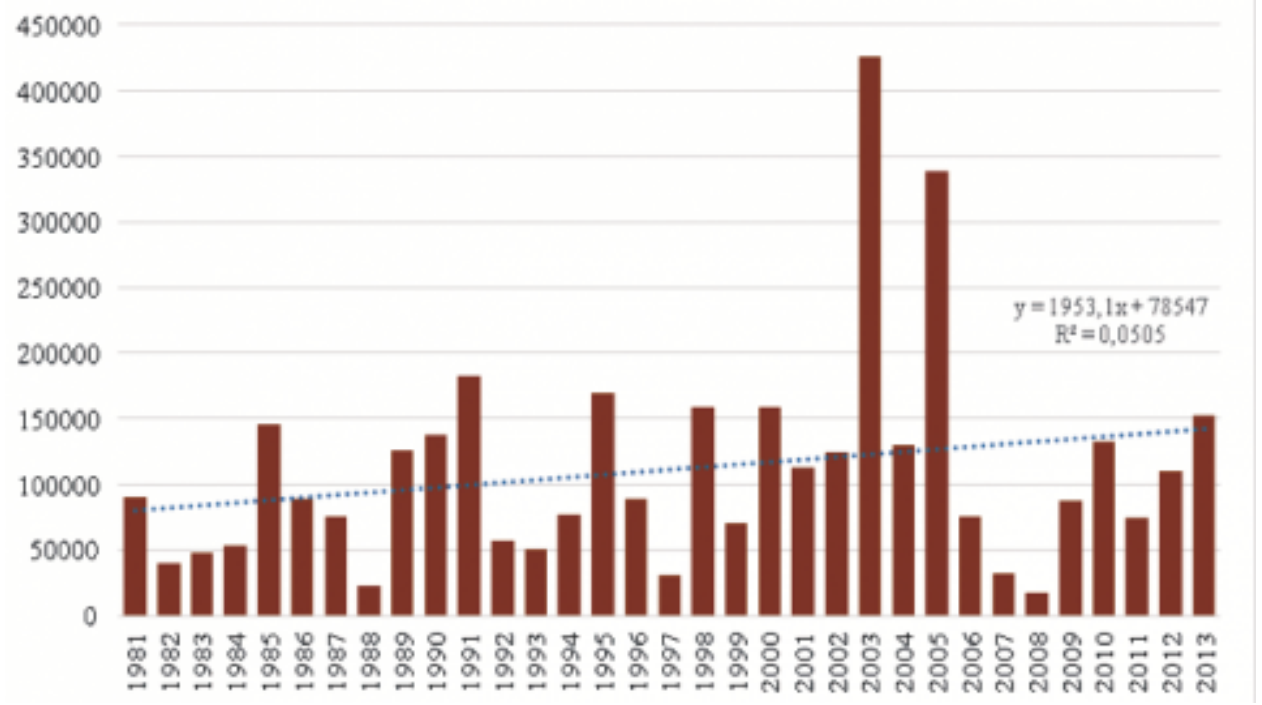

Determination coefficient (R2). Source: ICNF, 2013.

46 Alongside these yearly fluctuations, there is also a spatial variability of forest fire occurrences (fig. 6). In the last decade of the 20th century, forest fires primarily affected the northern part of mainland Portugal, while they concentrate on central Portugal and Algarve at the beginning of the 21st century. If we compare this distribution with land cover changes (fig. 4), the relationship between forest fire occurrences and the loss of forest areas becomes clearer.

Figure 6 - Spatial distribution of forest fires (1990-2015) in mainland Portugal 


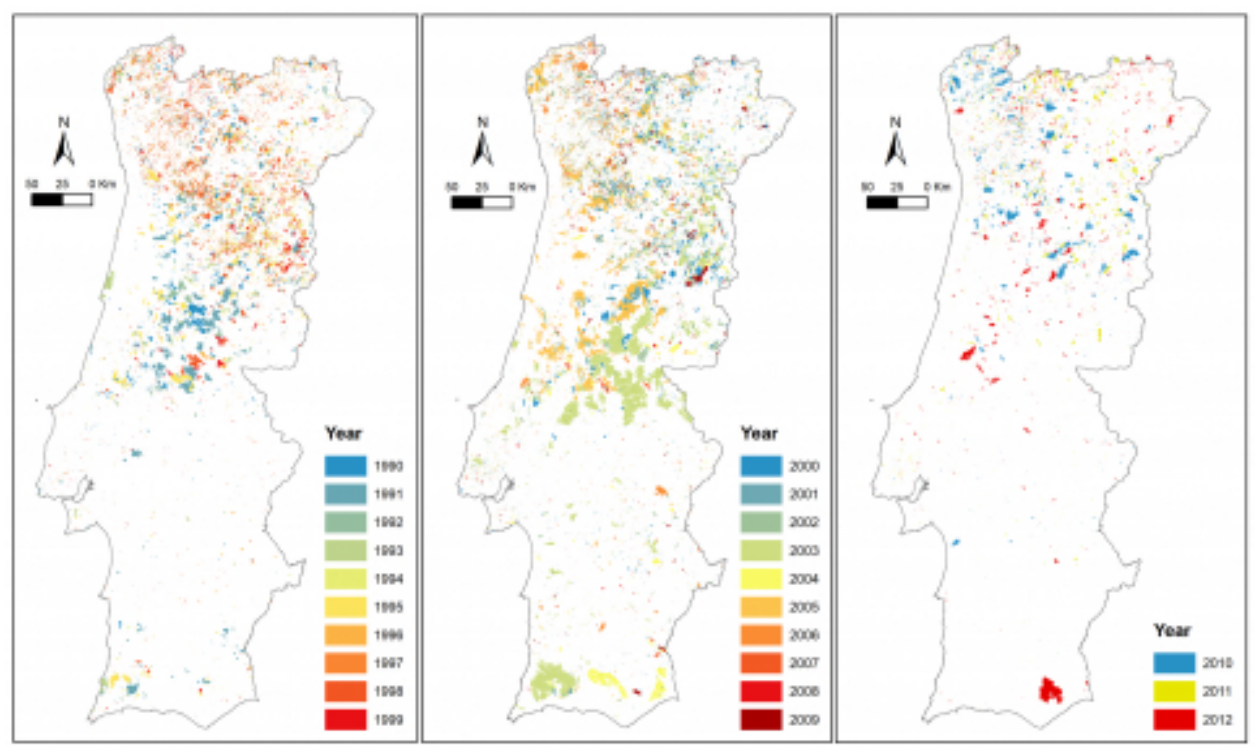

Analyzing the dynamics of each class of land occupation as a function of the "entries" and "exits" of areas in the class, in the period under consideration we verified that the artificialized territories are the only class without striking transitions. However, it is the natural vegetation that registers the highest area growth in mainland Portugal (914,900 ha), plus a lower transfer value for other classes, especially when compared to forest and agricultural areas (fig. 7).

Fig. 7 - Inputs and outputs by land use class between 1990 and 2012

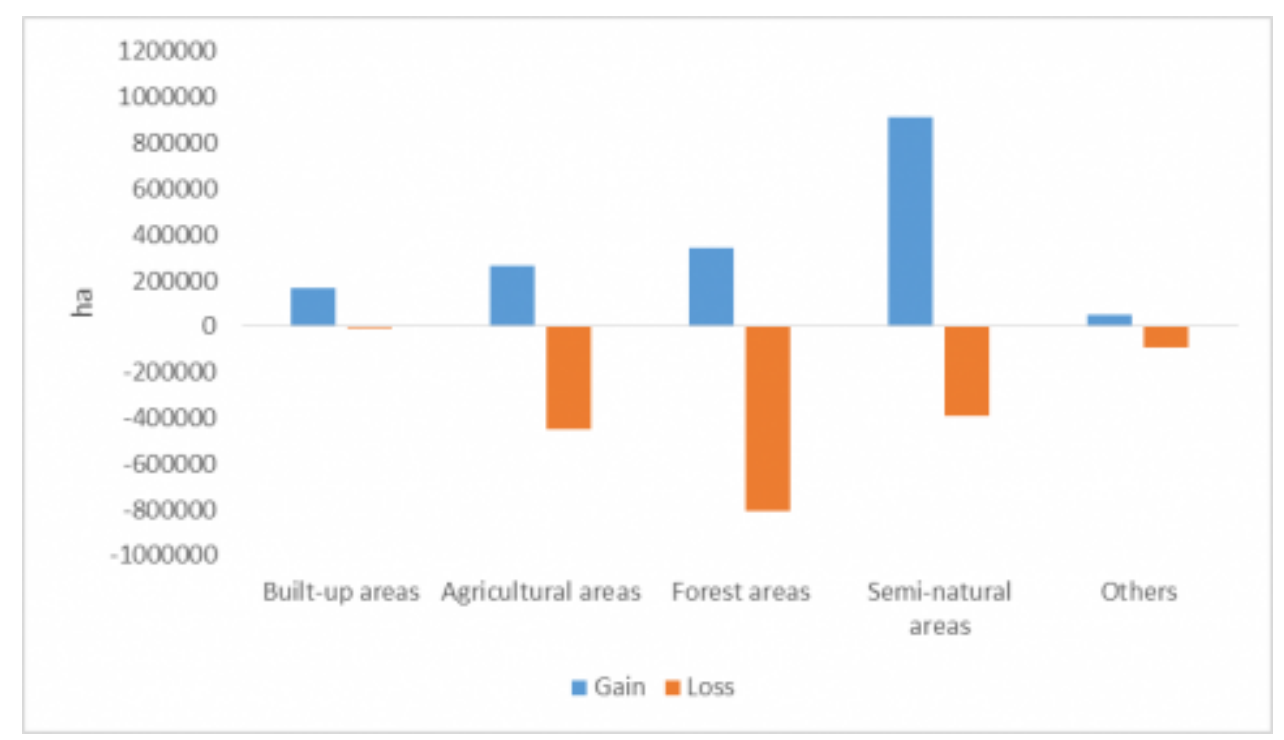

Source: CLC, 1990 and 2012.

Agriculture, although expanding to new areas (263,171 ha), had an absolute decrease in its area of 185,199 ha, since 448,370 ha of the national territory was no longer exploited for agricultural uses. From 1990 to 2012, forests have lost 803,810 ha (it was the class with the highest loss), with only 343,016 having been converted into a forest area, which results in a total decrease of forest areas of 460,794 ha. This is partially due to forest fire occurrences and the significant increase in the extent of burned areas (in the years 2003 and 2005 about 750,000 ha have been affected by fires). However, other causes are also responsible for the reduction of forest areas, namely the continuing rural exodus, as well as the loss of competitiveness of agricultural and forest economic activities, especially in inland economically depressed areas.

Between entries and exits, we verified that natural vegetation, together with artificialized territories, constitute the classes in which the entrances of new areas are superior to the exits of areas to other classes (fig. 8).

Fig. 8 - Variation of the area of each class between 1990 and 2000 


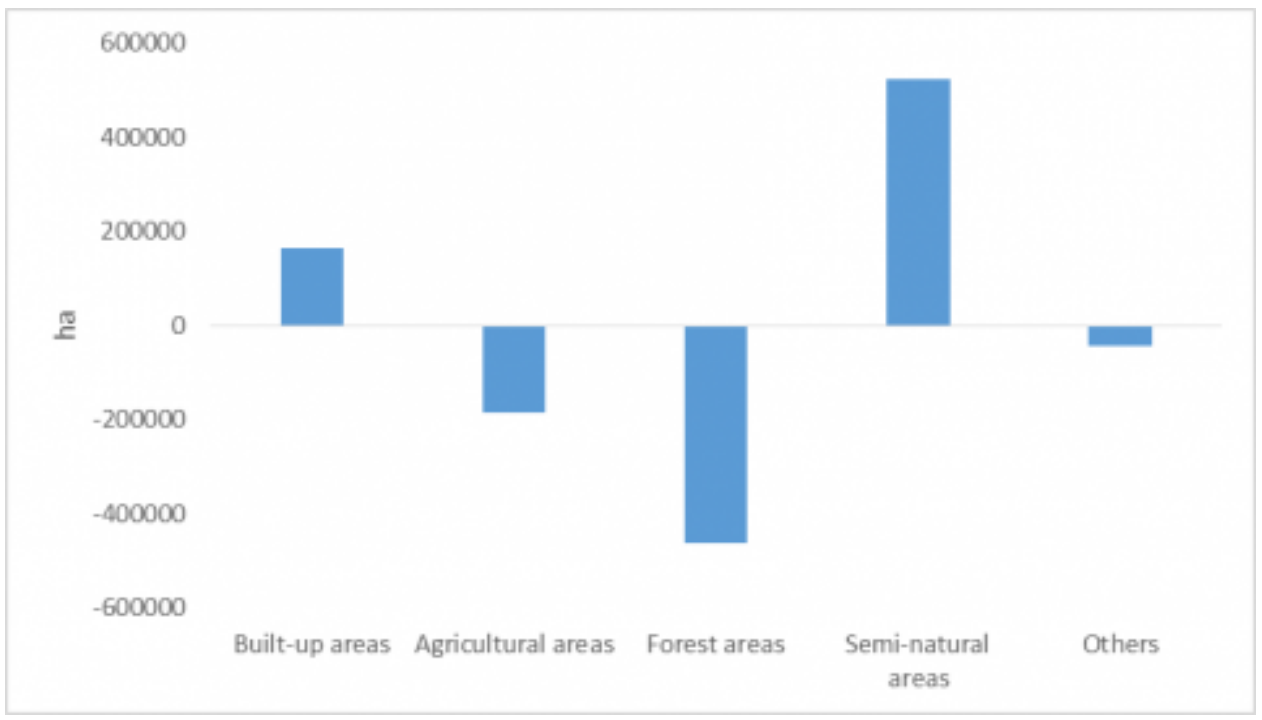

Source: CLC, 1990 and 2012.

Analyzing the transitions between classes in mainland Portugal in the period in question, the most important transitions were from forest to natural vegetation (607,999 ha), from natural vegetation to forest (248,064 ha), and from agriculture to natural vegetation (229,962 ha) (fig. 9).

Fig. 9 - Transition area between land use classes between 1985 and 2012 (in ha)

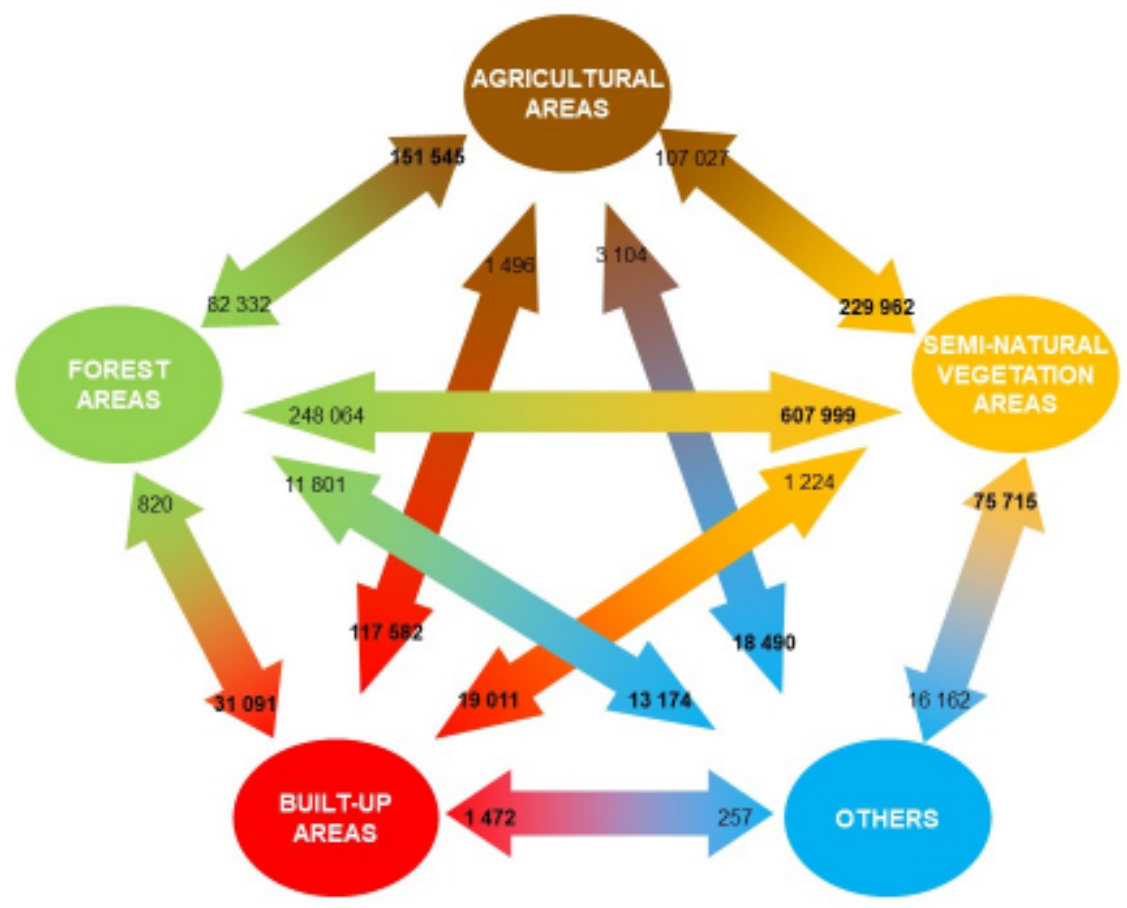

Source: CLC, 1990 and 2012.

This confirms the findings mentioned above. More precisely, it confirms, on the one hand, the marked reduction of forest areas, with a transfer mainly to natural vegetation but also to agricultural areas. This transfer was only mitigated by the recovery of an important area of natural vegetation. However, this was still not enough to balance the transfer between both classes. On the other hand, there was a significant increase in areas of semi-natural vegetation, provided by the transferences of both forest and agricultural areas. Artificial areas also grew significantly, mostly at the expense of agricultural areas and natural vegetation.

\section{Final Notes}


The Portuguese national territory has undergone significant social, political, demographic, economic, and environmental transformations during the second half of the twentieth century and beginning of the twenty-first century. These transformations had an unquestionable reflection on how the territory was managed and, especially, how it was occupied.

Forests play an important role in terms of landscapes, and bring benefits to the economy, environment, and society. Adequate management may be one of the engines for the country's development, particularly in regions which are at the fringe of the main drivers of economic growth.

The brief analysis made along this work shows that this important natural and economic resource has suffered, during the analysis period, a significant reduction in area, linked to social and economic factors (population exodus from inland to urban areas, loss of competitiveness) and aggravated by forest fires, causing its destruction and hampering its recovery.

\section{Bibliography}

ARONOFF S., (1982), Classification accuracy: A user approach, Photogrammetric Engineering and Remote Sensing, vol. 48, n. 8, p. 1299-1307.

BDJUR, (2008), Áreas Protegidas, Edições Almedina, SA, Coimbra

BENTO-GONÇALVES A., (2006), Geografia dos incêndios em espaços silvestres de montanha: o caso da Serra da Cabreira, Tese de doutoramento em Geografia, ramo de Geografia Física e Estudos Ambientais de Ciências Sociais, Universidade de Coimbra.

BENTO-GONÇALVES A., VIEIRA A., MARTINS C., FERREIRA-LEITE F., COSTA F., (2010), A desestruturação do mundo rural e o uso do fogo - o caso da serra da Cabreira (Vieira do Minho), in Caminhos nas Ciências Sociais. Memória, Mudança Social e Razão - Estudos em Homenagem a Manuel da Silva Costa, Edited by: Moisés de Lemos Martins Braga, Univ. do Minho, Grácio Editor, p. 87-104.

BRANCO M. C., COITO A., (2005), Servidões e Restrições de Utilidade Pública, $4^{\mathrm{a}}$ edição, DGOTDU, Lisboa.

CAETANO M., NUNES V., ARAÚJO A., (2006), Manual da Carta de Ocupação do Solo de 2005 para Portugal Continental, Grupo de Detecção Remota, Instituto Geográfico Português, Lisboa.

CAETANO M., NUNES V., ARAÚJO A., (2008), Concepção e desenvolvimento das especificações técnicas da nova Carta de Ocupação do Solo de Portugal Continental, Grupo de Detecção Remota, Instituto Geográfico Português, Lisboa.

CAETANO M., PEREIRA M., CARRÃo H., ARAÚJO A., NUNES A., NUNES V., (2008), Cartografia temática de ocupação / uso do solo, Instituto Geográfico Português, Lisboa.

CALVO D., MOLINA M. T., SALVACHÚA J., (1996), Ciencias de la Tierra y del Medio Ambiente, McGraw - Hill/ InterAmericana de España, SA, Madrid.

CANTER L. W., (1996), Environmental Impact Assessment, McGraw - Hill series, 2nd edition.

CONGALTON R. G., GREEN, K., (1999), Assessing the accuracy of remotely sensed data: Principles and practices, Lewis Publishers.

DEÁK C., (1985), Rent theory and the price of urban land. Spatial organization in a capitalist economy, PhD Thesis, Cambridge.

Feio M., (1997), Os principais Tipos de Utilização do Solo no Alentejo Meridional de 1885 a 1951, Revista Finisterra, vol. XXXII, no 63, p. 147-158.

FERREIRA J. M., (1990), O ordenamento do Território e as Áreas Protegidas, DGOTDU, Lisboa.

FERREIRA-LEITE F., BENTO-GONÇALVES A., VIEIRA A., NUNES A., LOURENÇO L., (2016), Incidence and recurrence of large forest fires in mainland Portugal, Natural Hazards $\mathrm{n}^{\circ} 84$, p.1035-1053.

GARCIA R., (2006), Sobre a Terra, Um guia para quem lê e escreve sobre ambiente, Público Comunicação Social, SA, $2^{\text {a }}$ edição.

GLASSON J., THERIVEL R., CAHDWICK A., (1994), Introduction to Environmental Impact Assessment, UCL press.

HENRIQUES A. G., (1991), Processo de AIA, Avaliação de Impacte Ambiental, Laboratório de Engenharia Civil, Lisboa.

LEMA P., REBELO F., (1996), Geografia de Portugal, Meio Físico e Recursos Naturais, Universidade Aberta. 
LOURENÇO L., BENTO-GONÇALVES A., VIEIRA A., NUNES A., FERREIRA-LEITE F., (2012), Forest Fires in Portugal, in Bento-Gonçalves A. and Vieira A, Portugal: Economic, Political and Social Issues, Nova Science Publishers, p. 97-111.

MAGAlHÃES M. R., (2001), A Arquitectura Paisagista. Metodologia e Complexidade, Editorial Estampa, Lisboa.

PAINHO M., CAETANO M., (2006), Cartografia de ocupação do solo: Portugal continental, 1985-200o: CORINE Land Cover 200o, Instituto do Ambiente, Amadora.

PARDAL S. (Ed.), (2004), Estudo Sobre o Novo Diploma para a RAN, REN e Disciplina da construção fora dos perímetros urbano, Instituto Superior de Agronomia, Universidade Técnica de Lisboa.

PARTIDÁRIO M. R., JESUS J., (1994), Avaliação do Impacte Ambiental, Centro de Estudos de Planeamento e Ambiente, Litografia Amorim.

PINHO P., PARTIDÁRIO M. R., (s/data), Guia de Apoio ao novo regime de Impacte Ambiental, IPAMB, Ministério do Ambiente e do Ordenamento do Território.

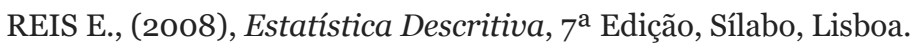

RIBEIRO O., LAUTENSACH H., DAVEAU S., (1999), Geografia de Portugal II. O Ritmo Climático e a Paisagem, Edições João Sá da Costa, Lisboa.

SARMENTO P. A. R., (2007), Avaliação da exatidão temática de cartografias de ocupação do solo: abordagem aplicada a mapas derivados de imagens de satélite de média resolução espacial (trabalho de fim de curso), Universidade de Évora, Évora.

SHOENMAKERS B.J., (2003), Desenvolvimento de uma metodologia de amostragem para caracterização da ocupação do solo em Portugal Continental, Universidade Nova de Lisboa, Lisboa.

TELLES G. R., CABRAL F. C., (2005), A Árvore em Portugal, Assírio e Alvim, Odivelas.

\section{Notes}

1 The General Direction of the Territory (DGT) is an entity responsible for the production of land cover and land use maps for mainland Portugal, namely the Land Cover Map (COS) and the CORINE Land Cover (CLC). The COS is a national product and includes a time series with three reference years (1995, 2007 and 2010). The CLC is a European cartography produced by DGT in coordination with the European Environment Agency (EEA) and includes a time series with four years of reference (1990, 2000, 2006 and 2012). The National Forestry Inventory (IFN), which is a statistical and cartographic process, has the objective of evaluating the abundance, state and condition of forest resources, and is produced by the Nature and Forest Conservation Institute (ICNF). At the IFN, the production of statistics is based on sampling processes, which are performed in different steps that make up a global Inventory task. The last IFN dates from 2010 and is only available in the provisional data. Thus, the option for the use of Corine Land Cover was due to the fact that it is a European cartography, which allows comparisons with other countries of the European Union, and presents information since 1990, allowing an evolutionary study until 2012.

\section{List of illustrations}

\begin{tabular}{|c|c|c|}
\hline \multirow{11}{*}{ is } & \multirow{3}{*}{$\begin{array}{c}\text { Title } \\
\text { Credits } \\
\text { UيRي }\end{array}$} & $\begin{array}{l}\text { Fig. } 1 \text { - Floristic regions in Europe according to Wolfgang Frey and } \\
\text { Rainer Lösch }\end{array}$ \\
\hline & & Source: https://commons. wikimedia.. rg/w/index. php?curid=3790054. \\
\hline & & $\begin{array}{l}\text { http://journals.openedition.org/mediterranee/docannexe/image/10025/img- } \\
\text { 1.jpg }\end{array}$ \\
\hline & File & image/jpeg, 448k \\
\hline & Title & $\begin{array}{l}\text { Fig. } 2 \text { - Excerpt from the map accompanying the "Report on the General } \\
\text { Arborization of the Country" }\end{array}$ \\
\hline & Uي. & $\begin{array}{l}\text { http://journals.openedition.org/mediterranee/docannexe/image/10025/img- } \\
\text { 2.jpg }\end{array}$ \\
\hline & File & image/jpeg, $1.3 \mathrm{M}$ \\
\hline & \multirow{2}{*}{$\begin{array}{c}\text { Title } \\
\text { Caption }\end{array}$} & Table I \\
\hline & & Land use between 1990 and 2012, by large groups of land use (\%). \\
\hline & \multirow{2}{*}{$\begin{array}{c}\text { Credits } \\
\text { URي }\end{array}$} & Source: a) CLC, 1990; b) CLC, 2000; c) CLC, 2006; d) CLC, 2012. \\
\hline & & $\begin{array}{l}\text { http://journals.openedition.org/mediterranee/docannexe/image/10025/img- } \\
\text { 3.jpg }\end{array}$ \\
\hline
\end{tabular}


File image/jpeg, 16k

Title Table II

Caption Land use in mainland Portugal, 2012.

Credits Source : CLC 2012.

URL http://journals.openedition.org/mediterranee/docannexe/image/10025/img4.jpg

File image/jpeg, 20k

Title Fig. 3 - Distribution of land covers in mainland Portugal, 1990 and 2012

Credits Source: CLC, 1990 and 2012; DGT.

URL http://journals.openedition.org/mediterranee/docannexe/image/10025/img5.jpg

File image/jpeg, 2.2M

Title Table III

Caption Distribution of forest areas by species group in mainland Portugal (1990 and 2012).

Credits Source: CLC, 1990 and 2012.

URI http://journals.openedition.org/mediterranee/docannexe/image/10025/img6.jpg

File image/jpeg, 28k

Title Fig. 4 - Changes in land cover in mainland Portugal between 1990 and 2012

Credits Source: CLC, 1990 and 2012; DGT.

URL http://journals.openedition.org/mediterranee/docannexe/image/10025/img7.jpg

File image/jpeg, $1.1 \mathrm{M}$

Title Fig. 5 - Evolution of burned areas in mainland Portugal between 1981 and 2013 (ha)

Credits Determination coefficient (R2). Source: ICNF, 2013.

URL http://journals.openedition.org/mediterranee/docannexe/image/10025/img8.png

File image/png, 440k

Title Figure 6 - Spatial distribution of forest fires (1990-2015) in mainland Portugal

UيLي http://journals.openedition.org/mediterranee/docannexe/image/10025/img9.jpg

File image/jpeg, $1.5 \mathrm{M}$

Title Fig. 7 - Inputs and outputs by land use class between 1990 and 2012

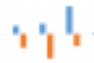

Credits Source: CLC, 1990 and 2012.

URI http://journals.openedition.org/mediterranee/docannexe/image/10025/img10.png

File image/png, 11k

Title Fig. 8 - Variation of the area of each class between 1990 and 2000

Credits Source: CLC, 1990 and 2012

URL http://journals.openedition.org/mediterranee/docannexe/image/10025/img11.png

File image/png, 9.2k

Title Fig. 9 - Transition area between land use classes between 1985 and 2012 (in ha)

Credits Source: CLC, 1990 and 2012.

URI http://journals.openedition.org/mediterranee/docannexe/image/10025/img12.jpg

File image/jpeg, 85k

\section{References}

Electronic reference 
António Bento-Gonçalves, António Vieira, Luís da Vinha and Safa'Hamada, « Changes in mainland Portuguese forest areas since the last decade of the XXth century », Méditerranée [Online], 130 | 2018, Online since 08 November 2018, connection on 30 March 2019. URL : http://journals.openedition.org/mediterranee/10025 ; DOI : 10.4000/mediterranee.10025

\section{About the authors}

\section{António Bento-Gonçalves}

Centro de Estudos em Geografia e Ordenamento do Território (CEGOT), Departamento de Geografia, Universidade do Minho, Campus de Azurém, 4800-058 Guimarães, bento@geografia.uminho.pt

By this author

Large forest fires in mainland Portugal, brief characterization [Full text]

Les grands incendies de forêt au Portugal, courte présentation

Published in Méditerranée, 121 | 2013

\section{António Vieira}

Centro de Estudos em Geografia e Ordenamento do Território (CEGOT), Departamento de Geografia, Universidade do Minho, Campus de Azurém, 4800-058 Guimarães, vieira@geografia.uminho.pt

\section{Luís da Vinha}

Centro de Estudos em Geografia e Ordenamento do Território (CEGOT), Social Science

Department, Valley City State University, Valley City, ND 58072, luis.davinha@vcsu.edu

\section{Safa'Hamada}

Centro de Estudos em Geografia e Ordenamento do Território (CEGOT), Geography

Department, An Najah National University, Nablus, Palestine, S.Hamada@najah.edu

\section{Copyright}

Tous droits réservés 